\title{
Does Pakistan's Intellectual Property Law Conform to International Intellectual Property Law? An Overview
}

Dr. Ghulam Murtiza*, Dr. Qamar Abad**

\begin{abstract}
Piracy and counterfeiting are not a problem of any one country or region but these evils have engulfed the whole world. That's why in the presence of these evils we are unable to take advantage of the benefits of intellectual property. To eradicate these evils, each country has its own laws in accordance with international intellectual property law. Pakistan also has intellectual property laws. This research seeks to determine whether Pakistan's intellectual property law is in line with international intellectual property law. For this purpose, an overview of legal and institutional framework for intellectual property in Pakistan and at international level has been taken. This study concludes that Pakistan's intellectual property law conforms to international standards and the only requirement is that these laws be enforced effectively.
\end{abstract}

Key Words: Intellectual property, Legal, Institutional, Protection

This Article can be cited as:

Murtiza G., Abad Q., (2020). Does Pakistan's Intellectual Property Law Conform to International Intellectual Property Law? An Overview, Journal of Arts and Social Sciences. VII (2), 245-255.

\footnotetext{
* Correspondence concerning this article should be addressed to Dr. Ghulam Murtiza, Assistant Professor, College of Law, Government College University, Faisalabad, ghulammurtiza@gcuf.edu.pk.

** Dr. Qamar Abad, Incharge Ph.D. Programme, School of law, University of Karachi, qamarabad@gmail.com.
} 


\section{Introduction}

Intellectual property is the creation of mind consisting of inventions, images, names, symbols used in commerce as well as literary, artistic works, inventions etc. (Janjua \& Samad, 2007). Intellectual property represents the rights stemming from creative actions in arts, science, literature and industry (DabovicAnastasovska \& Zdraveva, 2009). It deals with corporeal matters. It does not deal with incorporeal matters but with rights regarding spiritual material (Olssen, 2004). IP is intangible property that comes into being from human creation. This along with natural resources as well as material goods becomes part of national wealth (Nastase, 2010). It is product of mind and originates from human innovation and creativity (Nivas, 2010).

It permits people to own their creativity as well as invention like they own their physical property and indeed it is valued asset (Nwokocha, 2009). It is property which is creativity of mind. When a person uses his mind, brain, faculty to create something and in result of that which thing comes into being is called intellectual property. It may be visible or invisible (Singh, 2006). It refers to creations of mind (WIPO, 2003). It refers to the rights connected with intellectual activity in artistic, literary as well as scientific and industrial field (Sheikh \& Khan, 2014). IP is found almost everywhere - in works like music, art, films, and records, in objects like cars, drugs, computers and different kinds of plants, in signs and features like trademarks and designs (International Chamber of Commerce [ICC] \& WIPO, 2011). It means such rights resulting from intellectual action in science, industry, art and literature field (Chaudhry \& Iqbal, 2005).

Does Pakistan's Intellectual Property Law conform to International Intellectual Property law? To answer this question, an overview is taken of legal and institutional framework for intellectual property in Pakistan and at international level.

\section{International Law Framework for Intellectual Property}

UDHR Article 27 and ICESCR Article 15(1) protect the moral and material interests of authors (Al-Sharieh, 2016). Essentially, the human rights safety of intellectual property operates in combination with the technical frameworks established under WIPO and WTO. This aligned care benefits not only the owner, but also the community at large. Intellectual property legal dynasty is mainly administered by two entities, WIPO and the WTO (Sheikh \& Khan, 2014).

\section{WIPO}

On 14 July 1967, in a Convention in Stockholm, approval was granted to set up WIPO. In 1970, it entered into force. In December 1974, WIPO was ultimately recognized as United Nations specialized firm mainly with the aim to assist other United Nations agencies in its field of competence. The developing countries started to join the organization in the late 1960s and early 1970s with this belief that this alliance would help them to develop technology transference to their economies (Olwan, 2011).

WIPO is a global agency. Its main purpose is to preserve the works of human mind. It promotes the use of works of human brain. These works that are called IP develop the bounds of science $\&$ technology and improve the world of the creativity. Through its work, WIPO is playing a significant role in increasing the enjoyment and quality of life. Its role in creating real wealth of nations cannot be ignored (Jelisavac, 2004).

The objective of WIPO is to advance and harmonize intellectual property laws internationally. Within UN system, the actual responsibility of the organization is significantly broader: to encourage original mental work and to make easy the transference of technology with regard to industrial property to the developing nations for economic, social and cultural development (Boyle, 2004).

WIPO charged with international property is the key agency of multilateral system. WIPO has performed a significant function in promoting and strengthening IP rights as well as their use and 
implementation across the world over the past five decades. WIPO boasts a larger budget to support the modernization of intellectual property system in developing countries than any other single organizations, national or international. It is a forum of intergovernmental negotiations on new legal instruments. WIPO is a debate forum how intellectual property can meet with a range of public policy goals- from public health to food security (Birkbeck, 2016).

WIPO administers 23 international treaties regarding intellectual property protection. Co-operation for development program is also administered by it. This program is for developing and least developed countries. Through this program, help is provided to draft the legislation with regard to IPRs. The task of training courses concerning intellectual property preservation also comes within the ambit of this program. This program performs its work in close collaboration with other WIPO programs. This program provides professional advice regarding law making in different IP areas. To create awareness and to modernize regional and national IP structure comes within the sphere of this program. The special service in the field of unified administration of copyright and connected rights is provided to developing countries through this program (Blakeney, 2005).

Two widely known international IPR agreements Paris Convention and Berne Convention are administered by WIPO. The convention concluded in Paris deals with preservation of industrial property whereas convention concluded in Berne addresses the issues of copyright (Horan, Johnson \& Sykes, 2005).

\section{WTO}

On April 15, 1994, in an agreement in Morocco, approval was granted to establish WTO, superseded GATT, set up after Second World War. WTO was created by the Uruguay Round of 1986-1994 as the international institution with the responsibility to govern trade relationships. On January 1, 1995, WTO came into effect and in turn established international economic law, the public legal regime of trade rules among nations who are members of WTO (Yueh, 2006a).

WTO is responsible to supervise the anticipated additional reforms under the 1994 GATT, GATS, TRIMS and TRIPS (Wangwe, 2002).

The main purpose of WTO is to provide trade related discussion forum. It supervises national trade plans, addresses trade disputes, administers WTO trade agreements, cooperates with international organizations and provides technical assistance and training to developing countries (Sheikh \& Khan, 2014).

Today, the main task of WTO is to fulfill the dream of free trade. This dream can only be fulfilled by following the fundamental WTO principles. These principles are easy market access, impartial competition, reciprocation and no favoritism (Popović-Petrović, 2004).

\section{TRIPS Agreement}

On 1 January 1995, TRIPS entered into force. Regarding IP, this is a far-reaching multilateral contract and considered a big achievement of Uruguay Round of trade discussion. This agreement sets up minimum standards with regard to IP preservation. The member states may adopt huge-scale IP safety measures if they have desire to do so within the ambit of their legal system. The members countries have been given free hand to settle the suitable procedure for implementation of this contract (Jelisavac, 2004).

TRIPS pact covers IPRs inclusive of copyrights, trademarks, patents, industrial designs and GI. Unlike WIPO conventions, TRIPS provides minimal requirements of preservation of IPRs, the focus of which is only to implement the national legislation (Wangwe, 2002). It is the first agreement to introduce intellectual property rules into the multilateral trading system. It requires member countries to develop mechanisms to enforce these rights (Villiger, n. d.). TRIPS charter was drafted to address the provision and 
applicability of adequate IPRs. It provides pattern how to implement these rights. It tells how to settle multilateral controversies. It provides temporary plans (Adegoke, 2011).

TRIPS deal is a multilateral IP agreement which provides structure to resolve the IP disputes between governments. It covers trademarks, patents, copyrights and the rights connected with copyrights. These connected rights are rights of broadcasters and performers. The rights of producers of videos, compact discs and records are also examples of connected rights. TRIPS contract also covers GI. The industrial designs and lay out designs of integrated circuits are also come within the ambit of TRIPS. It provides minimal requirements of preservation of IPRs. It grants remedies and procedure to member states through which IPRs can be implemented. It tells how to resolve the IP disputes by using the dispute resolution procedure of WTO. It extends the WTO fundamental principles of transparency, national treatment and most favored nation strategy to IPRs (Horan et al., 2005).

The most significant development of Uruguay Round of 1986-94 was the addition of TRIPS. Before the TRIPS Agreement, this significant topic of IPRs was regulated by Paris Convention concluded in 1863, Berne Convention concluded in 1886, 1891Madrid Agreement, 1952 Universal Copyright Convention, Rome Convention of 1961, 1971 Geneva Convention \& IPIC Treaty of 1989 (Bagchi, 2007).

The TRIPS Agreement was developed to diminish piracy, counterfeiting and infringement of intellectual property rights. The purpose of agreement was to remove any barriers to trade as a result of piracy, counterfeiting and infringement. In essence, the objective of agreement was to remove obstacles in way of global trade. This pact was drafted to increase the competence and substantial safety of IPRs (Ofili, 2014). WTO developed member nations were asked to implement TRIPS in all respects. The deadline was given 1 January 1996. As developing nations were not in a position to implement TRIPS completely, they were given deadline until 1 January 2000 and in exceptional cases until 1 January 2005. However, many nations are still in process of finalizing their IP legislation and some are still in process of developing a sound and efficacious IPRs implementation system (USTR, 2015).

TRIPS accord is the basic international agreement with the aim to promote the harmonization of national intellectual property rights dynasties. The motive of TRIPS is to propose modern policy and formula for global trade regarding the provision of: (1) sound guidelines and patterns in relation to availability, capacity and use of IPRs (2) effective as well as suitable means for the implementation of IPRs (3) productive and prompt methods for the multilateral stoppage and resolution of controversies between nations (Dutfield, 2000).

\section{National Treatment \& Most-Favored-Nation Treatment}

Article $3 \& 4$ of TRIPS 1995 conclude that with regard to the preservation of IP, each member shall deal with the public of other countries as it deals with its own public and any favor, immunity, advantage and privilege allowed by a member to the public of other countries shall unconditionally and immediately be provided to the public of all other members.

\section{Objectives}

Article 7 describes the motives of preservation and implementation of IP rights. According to this article, the main objective of preservation and implementation of IP rights is to develop the scientific innovation. This would help in transference and marketing of technology. The advantages can be taken from the manufacturers and users of scientific intelligence. This thing will be beneficial for socio-economic welfare and balance between rights and duties can be created.

\section{Standards under TRIPS}




\section{Scope}

According to Article 9.2, expressions shall be covered under the umbrella of copyright preservation. The mathematical concepts, operation mechanism, ideas and procedures do not come within the ambit of copyright preservation. Article 10.1 protects the computer programs as scholarly works. As far as the trademark is concerned, it is a sign or blend of signs which create difference between products of one firm from those of others. According to Article 27.1, patents can be achieved with regard to any invention. This invention can be a product or a process in all areas of technology. But there is a condition that the invention should be new. Its utilization should be in industrial sector. It should involve an ingenious step.

\section{Term of Protection}

Regarding copyright, according to Article 12, term would be life of the originator and fifty years (not less than 50 years in certain limited circumstances). According to Article 18, term of protection in case of trademark would be at least 7 years and renewable indefinitely. Article 33 suggests the term of protection for patent 20 years from the filing date.

\section{Relation to Existing Conventions}

Article 9.1 states that members would follow Berne Convention in case of copyright matters and according to Article 2.1; members would follow Paris Convention in matters regarding trademark and patent.

\section{Enforcement of TRIPS}

Article 41 through 61 addresses exclusively the enforcement of intellectual property rights. Article 41 examines that members shall include the procedures as well as remedies mentioned in TRIPS into their domestic laws in order to prevent any action of piracy and counterfeiting. With regard to IPRs, the procedures should be impartial and unprejudiced. They should not be expensive and complex. These procedures should not consume illogical time limits. These procedures should not contain undue delays. The written judgments should be there and preferably speaking orders. Without any delay, these speaking orders should be provided to the concerned parties.

Article 42 describes that members shall provide the right holders an opportunity of timely written notice with enough detail. This notice should include the basis of claim. In court, there should be representation by a liberated lawyer and right to present a claim or a defense including with supporting evidence.

Article 44 suggests that the judicial authorities can cease and stop orders to prevent infringement and mechanisms to restrict the entry of goods that violate IPRs in local channels of commerce.

According to Article 45, adequate damages would be payable as a result of infringement on the holder of IPRs as determined by judicial authorities. Article 51 to 60 deals with expansive standards for the preservation of IPRs.

Article 61 observes that in case of willful trademark and counterfeiting, members should provide procedures and punishments. These punishments should be in form of imprisonment and pecuniary fines. 


\section{Dispute Settlement under TRIPS}

Article 64 suggests that WTO dispute settlement procedures shall apply to disputes under the TRIPS Agreement.

\section{Legal and Institutional Framework for Intellectual Property in Pakistan}

\section{Intellectual Property Organization (IPO) Pakistan}

It is an independent body. It is administratively controlled by the cabinet division. On $8^{\text {th }}$ of April 2005, it was set up for effective IP management in country. The copyright office, the trademarks registry and patent and design office are part of this institution. The major function of new organization includes advice federal government on IP policy. All IP offices in Pakistan are controlled by it. It helps in creating awareness regarding IPRs. It ensures suitable implementation of IPRs. To preserve and strengthen IP, it manages and team up all govt. structures (IPO-Pakistan), 2017, Introduction).

Its vision is to support and preserve IPRs so that Pakistan can prove itself as an obedient and capable nation on global intellectual property map. Its mission is to unify and improve IP infrastructure so the goal of making Pakistan an IP based nation can be achieved (IPO-Pakistan, 2017, Vision \& Mission).

\section{The Copyright Ordinance, 1962(as amended in 2000)}

Section 18 states that a copyright is protected in any dramatic, literary, artistic or musical work published within the life time of the author until fifty years from the beginning of the calendar year next following the year in which the author dies. As per section 35, the owner of copyright can bestow any interest in copyright by license with signature in writing or by duty authorized agent. According to section 36 , where owner of copyright refuses to republish the work or does not allow the performance of work in public or he is not alive or he is unidentified or he cannot be tracked or found and it is against the public interest, an application can be forwarded to the board for compulsory license. The board upon receiving this application will give an opportunity of hearing to the owner and the reasons would be recorded by the board. If the board considers that withheld of work from public is against the public interest, it will allow the compulsory license of work.

Under section 45, there shall be a copyright board consisting of chairman and three to five members from bodies of authors, publishers, cinematograph industry etc. The registrar shall be its ex officio member. A person who is current or former high court judge or he has such qualifications which are essential for becoming a high court judge shall be the chairman.

Section 60 empowers the owner of copyright to avail the civil remedies in case of infringement by way of injunctions, damages and accounts etc.

Section 65A prohibits the importation and exportation of infringing copies. Section 65B empowers the customs officers to detain and confiscate any consignment of infringing copies upon the application of the owner. The process of detention and examination shall be concluded within the duration of 15 days of putting in place the application. The order of the custom authorities would be appealable.

Section 66 through 66E describes the offences for which the penalty is three year's imprisonment or fine to the extent of one hundred thousand rupees or both. These offences include publishing work translated or modified without the authority of the owner, unlawful production or trading of sound recording s' pirated copies, profiteering of audio-visual work or recording that is only for private usage, producing copies more than those permitted by the owner of copyright, unlawful rental of cinematographic works and computer programs. Section 67 through 70 discusses the offences for which penalty is two year's imprisonment or fine to the extent of one hundred thousand rupees or both. 
These offences include having plates with intention to make pirated copies, putting wrong detail in the register, producing or presenting fabricated evidence, wrong declaration with purpose to deceive any authority and false authorship. Under section 73, the court may order to dump pirated copies, plates or recording machinery. According to section 74, police has power to grab the pirated copies, plates and recording machinery. All crimes under this law are cognizable. They are also non-bail able.

\section{The Patents Ordinance, 2000}

According to section 7, any invention is patentable with the conditions that it should be new one. Its utilization should be in industrial sector. It should involve an ingenious step. A math formula, scientific plan or a discovery is not an invention. The work of literature, art, drama or music does not come within the definition of invention. An invention does not include a method, theory or rule for fulfilling an intellectual action. To play a game or to do a business or the presentation of information does not come within the description of invention. For the treatment of humans and for the treatment of animals, therapeutic, surgical and diagnostic procedures are not patentable. A patent cannot be awarded regarding an invention which is against public order and morality. An invention is not patentable which is for the preservation of life and health of plant, animal or human. Regarding an invention which is for the safety of environment, patent cannot be achieved. With regard to minor change in physical image of a chemical work, patent cannot be granted.

Under section 31, the patent term is 20 years from filing date. Section 45 empowers the controller to restore the lapsed patents upon receiving application of restoration. Section 46 through 48 empowers the high court, controller and federal government to revoke the patent and under section 49, controller has power to revoke the surrendered patent.

As per section 59, if the duration of 4 years has been passed from putting in place the patent application or the duration of 3 years has been passed from granting the patent, the controller on request, has authority to grant compulsory license.

In case of infringement of patent, the court may provide relief in shape of injunctions, damages or accounts under section 61. Against the decision of the controller and the federal govt., appeal may be filed in the high court under section 69. Such appeal will be filed within the duration of 3 months from the decision of the controller or the federal govt. and it will be in written form. According to section 70, the high court single judge will hear such appeal. However, the matter can be referred to the larger bench by the single judge. That kind of appeal will be determined within the duration of 12 months from filing date.

Section 71 through 77 describes the penalties for different kinds of offences under this ordinance. The fine to the extent of Rs. 5000 will be imposed in case of false representation. If the words "patent office" is used wrongfully, the penalty is 2 year's imprisonment and the fine to the extent of Rs. 1000000 will be imposed. The fine to the extent of Rs. 5000 will be imposed if a person refuses or fails to provide required information and if the information is false, the fine to the extent of Rs. 50000 will be imposed. The penalty of fine to the extent of Rs. 25000 will be awarded to the patent agent who is none registered.

\section{The Trademarks Ordinance, 2001}

Section 12 suggests that the trademark may be registered in respect of goods, services or both. The decision of registrar regarding classification shall be final. According to section 17, a trademark for which registration is required should be distinguishable from the earlier registered trademark. Likewise, the goods or services should be distinguishable from the goods or services for which the trademark has already been registered. 
Section 34 deals with the protection of trademark. The registration of trademark will be for the duration of 10 years from registration date. It is renewable for further duration of next 10 years under section 35 and it would be published in the journal. A trademark may be surrendered under section 38 .

Under section 46, in case of infringement of trademark, an action can be taken by the proprietor. He will be provided relief by way of damages, injunctions, accounts etc.

The revocation of registration of trademark may be made under section 73 . License to use the registered trademark may be granted under section 75 . It may be general or limited. The registered trademark may be surrendered by the proprietor in light of section 79 .

A person who applies false trade description will face penalty of imprisonment to the extent of 2 years but not less than 3 months or of fine not less than Rs. 50000 or of both under section 99 . Under section 100 , enhanced penalty of imprisonment to the extent of 3 years but not less than 6 months or of fine not less than one hundred thousand rupees or of both would be imposed on second or subsequent convictions. According to section 101, penalty for false entries in register is imprisonment to the extent of 2 years but not less than 3 months or fine not less than Rs. 50000 or both. Section 102 observes that a person will face the imprisonment to the extent of 6 months but not less than 1 month or fine not less than Rs. 2000 or both who deceitfully depicts a trademark as registered one. A person will face imprisonment to the extent of 2 years or fine or both who improperly describes a place of business as affiliated with trademark registry under section 107.

\section{The Registered Designs Ordinance, 2000}

According to section 7, the protection of design would be ten years. The heir of certified design will have unshared privilege regarding his design. The period of protection is renewable upon filing application of renewal and paying prescribed fee for the second and third time. Through written notice to the registrar, the registration of design may be surrendered by the owner.

If the registered design is violated, a suit may be brought by the heir against the violator demanding an injunction or compensation under section 8 . The section 10 states that any person may seek any time the abolition of design registration by a petition filed in the high court. The petition may also be filed to the registrar within two years of registration. The grounds of cancellation may be different including the design is against to public order and morality, the proprietor has no right to it, substantive requirements have not been fulfilled etc. Under this section, against any decision of registrar, appeal will be filed in the high court.

Any person under section 27 will face the penalty of imprisonment to the extent of 2 years or of fine to the extent of Rs. 20000 or both who does not fulfill the conditions under section 7 or forwards registration application in violation of that section. According to section 28 , in case of falsification of register, penalty would be of imprisonment to the extent of 2 years or of fine to the extent of Rs. 20000 or of both. Section 29 states that a person who falsely represents a design as registered, his penalty would be of fine to the extent of Rs. 1000.

\section{The Registered Layout-Designs of Integrated Circuits Ordinance, 2000}

According to section 5, when the layout design is protected, it cannot be reproduced, imported, sold or distributed. The protection duration of a registered layout design will be counted from its first commercial use and this duration would be for ten years under section 6 .

Section 13 deals with the cancellation of registered layout design. Any interested party may apply for cancellation. Under section 16, any person who sells, imports, reproduces the registered layout design without consent of the owner shall be punished with imprisonment to the extent of 2 years or fine not less than two hundred thousand rupees or both. 


\section{Conclusion}

To overcome the evils of piracy and counterfeiting, there was a need of proper legislation at international level. In 1995, WTO pact on TRIPS entered into force and brought with it a new age of preservation and implementation of IPRs. Provisions of TRIPS regarding copyright, geographical indications, patents, industrial designs, trademarks and lay out designs of integrated circuits precisely supplement the global agreements governed by WIPO secretariat. The legal and institutional framework for intellectual Property in Pakistan is at par with international standards. The only requirement is that these laws be enforced effectively.

\section{References}

Adegoke, S. (2011). Intellectual Property Rights in Sub-Saharan Africa.

Agreement on Trade Related Aspects of Intellectual Property Rights 1995. Retrieved on 11-05-2017 from https://www.wto.org/english/docs_e/legal_e/27-trips.pdf

Al-Sharieh, S. (2016). Toward a Human Rights Method for Measuring International Copyright Law's Compliance with International Human Rights Law. Utrecht J. Int'l \& Eur. L., 32,5 .

Bagchi, J. (2007). Intellectual property: global and Indian dimensions: Manas Publications.

Birkbeck, C. D. (2016). The World Intellectual Property Organization (WIPO): A Reference Guide: Edward Elgar Publishing.

Blakeney, M. (2005). Guidebook on Enforcement of Intellectual Property Rights. Queen Mary Intellectual Property Research Institute.

Boyle, J. (2004). A Manifesto on WIPO and the Future of Intellectual Property. Duke L. \& Tech. Rev., 2004, 9-15.

Chaudhry, G. M., \& Iqbal, C. M. Z. (2005). Chaudhry's the Intellectual Property, Intellectual Property Laws in Pakistan and International Treaties on IPRs: Federal Law House.

Dabovic-Anastasovska, J., \& Zdraveva, N. (2009). Strategy of Intellectual Property Rights of Republic of Macedonia 2009-2012. Ministry of Economy, State Office of industrial property, Skopje.

Dutfield, G. (2000). Literature survey on intellectual property rights and sustainable human development.

Froman, M. B. (2015). Special 301 Report Ambassador. United States Trade Representative, Executive Office of the President of the United States.

Horan, A., Johnson, C., \& Sykes, H. (2005). Foreign infringement of intellectual property rights: Implications for selected US industries. Retrieved from (No. 15883). United States International Trade Commission, Office of Industries

ICC \& WIPO (2011). Making Intellectual Property Work for Business. Retrieved on 27-04-2017 from http://www.wipo.int/edocs/pubdocs/en/intproperty/956/wipo pub 956.pdf 
Intellectual Property Organization of Pakistan (2017). Introduction. Retrieved on 29-09-2017 from http://www.ipo.gov.pk/

Intellectual Property Organization of Pakistan (2017). Vision \& Mission. Retrieved on 29-092017 from http://www.ipo.gov.pk/

Janjua, P. Z., \& Samad, G. (2007). Intellectual property rights and economic growth: The case of middle income developing countries. The Pakistan Development Review, 711-722.

Jelisavac, S. I. (2004). International regulation of intellectual property rights. Medjunarodni problemi, 56(2-3), 279-303.

Nastase, G. I. (2010). Methods for economic and financial analysis of intangible assets. The Annals of the" Stefan cel Mare" University of Suceava. Fascicle of The Faculty of Economics and Public Administration, 10(Special), 147-156.

Nivas, S. (2010). IP RIGHTS AND DIGITIZED CONTENT. Indian Journal of Computer Science and Engineering, 1(2), 977-980.

Nwokocha, Uche. (2009). Sub-Sahara Africa: Intellectual Property Rights Development. Retrieved on 17-04-2017 from http://www.mondaq.com/Nigeria/x/70872/Trademark/SubSahara+Africa+Intellectual+Property+ Rights+Development.

Ofili, O. U. (2014). Intellectual Property Rights Protection and Economic Development: The Case of Nigeria.

Olssen, H. (2004). Difficulties in the Enforcement of Intellectual Property Rights and Possible Solutions. WIPO National Workshop for Judges, Riyadh, Saudi Arabia

Olwan, R. M. (2011). Intellectual property and development: theory and practice. Queensland University of Technology.

Popović-Petrović, I. (2004). World Trade Organization: Establishment, functions, objectives. Medjunarodni problemi, 56(1), 93-113.

Sheikh, M., \& Khan, M. U. (2014). Understanding and developing Pakistan's Intellectual Property Law Framework. Found on 30-03-2017 under http://rsilpak.org/wpcontent/uploads/2016/03/Intellectual-Property-Brief.pdf

Singh, A. (2006). Enforcing Intellectual Property Rights in India. Found on 30-03-2017 under http://www.amarjitassociates.com/articles/speach-2.htm

The Copyright Ordinance 1962. Retrieved on 01-09-2017 from http://www.wipo.int/edocs/lexdocs/laws/en/pk/pk005en.pdf

The Patents Ordinance 2000. Retrieved on 02-09-2017 from http://www.wipo.int/wipolex/en/text.jsp?file_id=188949

The Registered Designs Ordinance 2000. Retrieved on 03-09-2017 from 
http://www.ipo.gov.pk/uploads/CMS/Registered_Designs_Ordinance_2000.pdf

The Registered Layout-Designs of Integrated Circuits Ordinance 2000. Retrieved on 04-09-2017 from http://www.wipo.int/edocs/lexdocs/laws/en/pk/pk004en.pdf

The Trademarks Ordinance 2001. Retrieved on 06-09-2017 from http://www.wipo.int/wipolex/en/details.jsp?id=3479

Villiger, D. (n.d.). Macroeconomic Effects of TRIPS on the Chinese Economy.

Wangwe, S. (2002). Country case study for Study 9: Institutional issues for developing countries in IP policy-making, administration and enforcement: Report commissioned by the Commission on Intellectual Property Rights.

WIPO (2003). What is Intellectual Property? Retrieved on 23-04-2017 from http://www.wipo.int/edocs/pubdocs/en/intproperty/450/wipo_pub_450.pdf

Yueh, L. Y. (2006). Global intellectual property rights and economic growth. Nw. J. Tech. \& Intell. Prop., 5, 436. 